\title{
University rankings: between market regulation and the diffusion of organizational models. The Brazilian case
}

\author{
António Teodoro, Eduardo Santos \& Reinaldo \\ da Costa Junior
}

\begin{abstract}
:
In this paper two of the better-known university rankings produced internationally are considered, the Academic Ranking World Universities (ARWU) and the Times Higher Education World Universities Rankings (THE), as well as a national ranking, the Folha University Ranking (RUF), focussed on Brazilian universities. The thesis we put forward is that rankings play a dual role, regulating the market and disseminating organizational models. The paper highlights the existence of differences between the concerns (and implications) of the international rankings (ARWU and THE) and the Brazilian national ranking (RUF), which sets out as main goals, on the one hand, to steer the elites' demand for tertiary education towards degrees with higher employability and, on the other, to provide indications which may be considered useful for the labour market to recruit better qualified professionals.
\end{abstract}

Keywords:

Brazil; universities; rankings; regulation; labour market. 


\section{Ranking universitários: entre a regulação do mercado e a difusão de modelos organizacionais. O caso brasileiro}

Resumo: Neste artigo, apresentam-se dois dos mais conhecidos rankings de universidades produzidos a nível internacional, o Academic Ranking World Universities (ARWU) e o Times Higher Education World Universities Rankings (THE), e um de natureza nacional, o Ranking Universitário Folha (RUF), que tem como foco as universidades brasileiras. A hipótese defendida é a de que os rankings desempenham um duplo papel, o de regulação do mercado e o de difusão de modelos organizacionais. O artigo mostra a existência de diferenças entre as preocupações (e implicações) dos rankings internacionais (ARWU e THE) e do ranking nacional brasileiro (RUF), que apresenta, como principal foco, por um lado, orientar a procura de formação superior por parte das elites em direção aos cursos com maior empregabilidade, e, por outro, fornecer indicações que possam ser consideradas úteis para o mercado de trabalho no recrutamento dos profissionais melhor qualificados.

Palavras-chave: Brasil; universidades; rankings; regulamento; mercado de trabal

\section{Rankings universitarios: entre la regulación del mercado y la difusión de modelos de organización. El caso brasileño}

Resumen: En este artículo se presentan dos de los más conocidos rankings de universidades producidas a nivel internacional, el Academic Ranking World Universities (ARWU) y el Times Higher Education World Universities Rankings (THE), y uno de naturaleza nacional, el Ranking Universitario Folha (RUF ), que tiene como foco las universidades brasileñas. La hipótesis defendida es que los rankings desempeñan un doble papel, el de regulación del mercado y el de difusión de modelos organizacionales. El artículo muestra la existencia de diferencias entre las preocupaciones (e implicaciones) de los rankings internacionales (ARWU y THE) y del ranking nacional brasileño (RUF), que presenta, como principal foco, por un lado, orientar la demanda de formación superior por parte de las élites hacia los cursos con mayor empleabilidad, y, por otra, proporcionar indicaciones que puedan ser consideradas útiles para el mercado de trabajo en el reclutamiento de los profesionales mejor calificados.

Palabras clave: Brasil; universidades; rankings; regulación; mercado laboral

\section{Rankings universitaires: entre la régulation des marchés et la diffusion des modèles organisationnels. Le cas du Brésil}

Résumé: Dans cet article, deux des rankings les plus connus des universités internationales, le Academic Ranking World Universities (ARWU) et le Times Higher Education World Universities Rankings (THE), et un rankings national, le Ranking Universitario Folha (RUF), qui se concentre sur les universités brésiliennes. L'hypothèse défendue est que les rankings jouent un double rôle, celui de la régulation du marché et de la diffusion des modèles organisationnels. L'article montre l'existence de différences entre les préoccupations (et les implications) des rankings internationaux (ARWU et THE) et du rankings national brésilien (RUF), dont l'objectif principal est, d'une part, de guider la demande d'enseignement supérieur en des élites vers des cours plus aptes au travail et, d'autre part, fournissent des indications qui peuvent être considérées utiles pour le marché du travail lors du recrutement des professionnels les plus qualifiés.

Mots-clés: Brésil; universités; rankings; règlement; marché du travail 


\section{Introduction}

Higher education systems have undergone intense transformation and, especially in the second half of the 20th century, experienced extraordinary expansion. The number of tertiary students worldwide has increased fivefold between 1970 and 2007, going from 28.8 million in 1970 to 152.5 million in 2007. But a closer look at the data reveals that the expansion has been particularly intense since 2000, with 51.7 million new students enrolled around the world in just seven years (UNESCO 2009). The same process, with identical vigour, has taken place in Latin America and especially in Brazil, which went from 87,603 students enrolled in higher education in 1959 to 6,152,405 students in 2013, i.e., an increase of over 70 times (Vieira and Nogueira 2017).

One of the driving forces of this change was the growing understanding that scientific research, technological innovation and the qualification of the populations are key factors in generating wealth, on which welfare and citizen safety systems ultimately depend. Increasingly globalized competition has been demanding new and readily applicable knowledge, shortening the cycle of technological innovation in almost all areas of manufacturing and society. At the beginning of the 21st century, the pace of scientific knowledge output doubled every five years, and it is projected that by 2020 it may double every 73 days (Tunnerman and Chauí 2003).

Higher education has acquired growing importance in fostering changes and the resolution of social and economic problems. It now integrates the set of topics considered priority and strategic to the development of nations and peoples. There is a widespread conviction that progress requires an increase in the levels of schooling of the populations and that development needs require flexibility, agility and training alternatives to match the expectations of a swift integration in ever-changing and constantly competing productive systems (Santiago, Tremblay, Basri, and Arnal, 2008).

In the past three decades, the prevailing discourse in higher education has become a way to legitimize a new relational order, based on the market, on the private and productive sectors, on economic competitiveness and on client-based management. This new paradigm of education corporatization is inscribed in the movement which highlights measurable and comparative dimensions, as well as constant evaluation and accountability. This is contábil education (Lima 2007), evidenced in an obsession with efficiency, efficacy, the systematic use of metaphors from the economic area and a pervasive discourse of quality, evaluation, results and rigour.

In many countries, particularly those which occupy the dynamic centre of the cumulation system, extensive changes have occurred in the governance of universities, taking corporate management modes as model and drawing nearer to them. As a direct consequence of applying the theories of new public management, the modes of collective participation (by lecturers, researchers, students) in the definition of scientific and 
training policies were considered inefficient, and replaced by the word and influence of stakeholders, by definition external to the university. Deans started being chosen like the CEOs (chief executive officers) of corporations and began acting according to identical efficiency standards. Even when these changes do not occur, new forms of management, based especially on service tertiarization and outsourcing, have been gradually adopted.

The most significant material change which sustains neoliberalism in the 21 st century is the rise in the relative weight of knowledge as capital (Olssen and Peters 2005; Tunnerman and Chauí 2003). In this environment, the role of higher education in economic competition and competitiveness has taken on even greater importance. Universities are seen as the key drivers of economic growth in the knowledge economy, and as such have been encouraged to build close links with industry and business, from a diversified set of partnerships. Recognizing the economic importance of higher education has led to numerous initiatives to adapt teaching to the promotion of business skills and to develop performative measures with this explicit goal in mind.

\section{International rankings}

In this paper, we consider two of the best known university rankings produced internationally - the Academic Ranking World Universities (ARWU), initially developed by the Shangai Shiao Tong University, China, and the Times Higher Education World Universities Rankings (THE), created by the British newspaper Times -, as well as a national ranking, the Folha University Ranking (RUF), prepared by the leading newspaper Folha de S. Paulo, focussing on Brazilian universities.

The thesis we put forward is that rankings play a dual role, (i) regulating the market, upstream, as regards student demand, as well as downstream, with the indications they provide companies to recruit university graduates, and (ii) disseminating organizational models, where the link between teaching, research and technological application becomes central. The implications of this thesis are multiple, and require further broad empirical work, but they show differences between the concerns (and implications) of world rankings (ARWU and THE) and the national Brazilian ranking (RUF).

\section{Academic Ranking of World Universities (ARWU)}

This ranking was published for the first time in June 2003 by the Center for World-Class Universities (CWCU), Graduate School of Education (formerly the Institute of Higher Education) of Shanghai Jiao Tong University, China. Since 2009, the Academic Ranking of World Universities (ARWU) has been published by ShanghaiRanking Consultancy, a fully independent organization on higher education intelligence, not legally subordinated to any universities or government agencies. Published yearly, ARWU lists 
globally the 5,200 best universities and comprehends two other specific rankings: by fields of knowledge and by specific subjects. It is the only ranking based on data already available internationally and it does not resort to peer-evaluation from surveys specifically conducted.

The general ranking uses six indicators grouped in four fields. To assess the quality of education, it considers the number of alumni of an institution who have received a Nobel Prize or a Fields Medal (for mathematics). The quality of faculty is assessed by two indicators: first, the number of Nobel laureates or Fields medallists; second, the number of highly-cited researchers in 21 scientific categories, compiled by the bibliometric company Thomson Reuteurs, which produces the Web of Science (WoS). The research output is also measured by two indicators: the number of papers published in the past five years by the university's faculty and researchers in Nature and Science; and the total number of papers published in journals indexed in the WoS, with special emphasis on social sciences. The performance of the institution is measured dividing the above mentioned five indicators by the number of academic staff and researchers of the university.

For each indicator, the institution with the highest total is assigned a score of 100 , all others then being classified from 0 to 100 according to their respective totals. Then, an aggregation is carried out for the total of indicators, with a normalization to 100 for the university with the highest score, and a classification from 0 to 100 for all others, depending on their respective aggregated results.

The authors of the ranking analyse over 1,200 universities, although only the first 500 are presented. The first 100 universities are given an ordinal classification, while the others are grouped in clusters of 50, up to 200 , and in groups of 100 for the remainder.

ARWU also includes two specific rankings. One is ARWU-FIELDS, with the 200 best universities in each of the following five fields of knowledge: (i) natural sciences and mathematics, (ii) engineering, technology and computer sciences, (iii) life and agricultural sciences, (iv) clinical medicine and pharmacy and (v) social sciences. The other ranking discriminates the 50 best universities in each of the following 52 academic subjects (in the order in which they are presented): Mathematics, Physics, Chemistry, Earth Sciences, Geography, Ecology, Mechanical Engineering, Electrical \& Electronic Engineering, Automation \& Control, Telecommunication Engineering, Instruments Science \& Technology, Biomedical Engineering, Computer Science \& Engineering, Civil Engineering, Chemical Engineering, Materials Science \& Engineering, Nanoscience \& Nanotechnology, Energy Science \& Engineering, Environmental Science \& Engineering, Water Resources, Food Science \& Technology, Biotechnology, Aerospace Engineering, Marine/ Ocean Engineering, Transportation Science \& Technology, Remote Sensing, Mining \& Mineral Engineering, Metallurgical Engineering, Biological Sciences, Human Biological Sciences, Agricultural Sciences, Veterinary Sciences, Clinical Medicine, Public Health, 
Dentistry \& Oral Sciences, Nursing, Medical Technology, Pharmacy \&, Pharmaceutical Sciences, Economics, Statistics, Law, Political Sciences, Sociology, Education, Communication, Psychology, Business Administration, Finance, Management, Public Administration, Hospitality \& Tourism Management, and Library \& Information Science.

The ranking was initially created to ascertain the standing of Chinese universities in the world of the great international universities. However, it soon became the most cited and influential ranking to classify the so-called world class universities. Nonetheless, it is still the target of strong and well-founded criticism ${ }^{1}$. The first is that practically all indicators refer only to one single mission of universities, i.e. research. Even when they refer to the quality of education and of the faculty, this is the only aspect considered. For instance, deeming that the count of Nobel laureates or Fields medallists may be an indicator of the quality of education of a university is surely fiction. There are in the world about 20,000 universities, and the odds of one having a graduate who has won one of these prizes are extremely reduced. And how does that correlate with the quality of the education taught, when it is well known that in general only scientists who are fairly advanced in age are awarded a Nobel Prize or a Fields medal?

The second and third indicators undermine universities with a strong element of social and human sciences and favour the institutions of the Anglo-American cultural universe. First, because the journals in the WoS, of the American company Thomas Reuteurs, are almost exclusively English-language journals, when we know that in social and human sciences publishing in the national language, as well as using other languages of transnational expression (Spanish, French, Portuguese, German), is an established practice. We must add that the third indicator, publication in Nature and Science, almost completely excludes social and human sciences. Finally, the indicators referring to output can be similarly criticised, namely, that they favour Anglo-American universities and underappreciate social and human sciences.

\section{Times Higher Education World University Rankings (THE)}

THE World University Ranking was published for the first time in 2004, one year after ARWU, in the Times Higher Education Supplement. Until 2009, the ranking was conducted by a consultancy company, Quacquarelli Symonds (QS), and was based on six indicators ${ }^{2}$. After this date, THE became the responsibility of the American company Thomas Reuters, which established a new methodology based on 13 differently weighed indicators grouped in 5 categories. These indicators aim to represent what is known as the core of university missions: teaching, research, knowledge transfer, and international recognition.

In November 2014, the Times Higher Education (THE) announced a new reform in methodology, severing the connection with Thomson Reuters. The main change involved data collection, previously undertaken by Thomas Reuters. Now, THE has 
assumed this responsibility directly and has assembled a team which, partnering with (unspecified) universities, seeks to build the broadest and most comprehensive database of universities in the world, including information on resources, faculty and research, student profile, both by institution and by scientific field, collecting data from hundreds of universities in every region of the world. Figure 1 summarizes the methodology used in THE ranking, by its own authors.

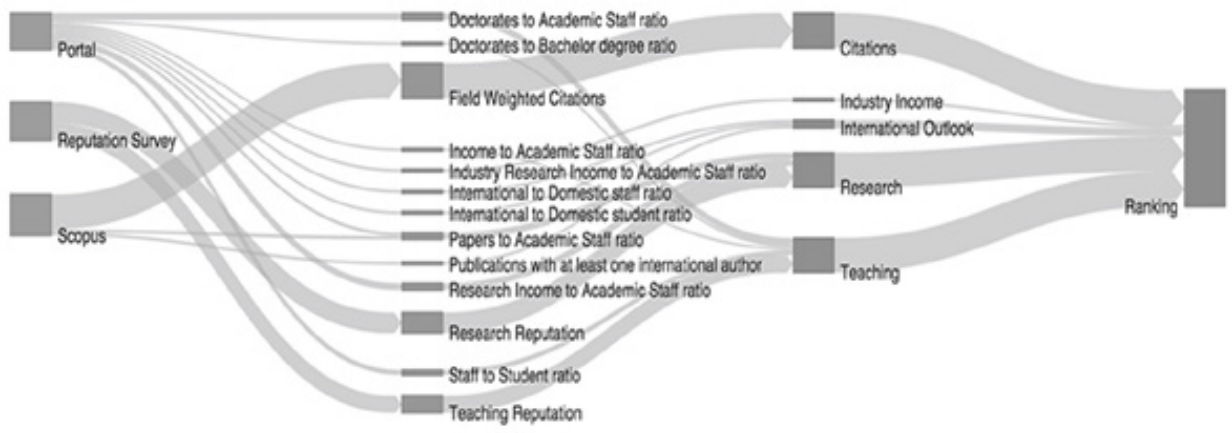

Figure 1. Methodology of THE World University Ranking (Source: THE Data Points)

As regards scientific output (and respective influence), data collecting was conducted by the European company Elsevier, through its Scopus database. The data have served to feed supplementary rankings such as THE Asia University Rankings or THE BRICS \& Emerging Economies Rankings. But the new trend seems to be publishing rankings by subjects, considering the following: Arts \& Humanities (art, performing arts, languages, history, philosophy, theology, architecture and archaeology), Education (education, teacher training, and academic studies in education), Law, Psychology, Business \& Economics (business and management, accounting and finance, and economics and econometrics), Clinical, pre-clinical \& health (medicine, dentistry and health's subjects), Computer Science, Engineering \& technology (electrical, mechanical, civil, chemical and general engineering), Life sciences (agriculture and forestry, biological sciences, sport science and veterinary science), Physical sciences (mathematics, statistics, physics, astronomy, chemistry, geology and environment sciences), and Social sciences (sociology, geography, political and international studies, and communication and media studies).

THE rankings are produced with data collected from three sources: (i) its own portal, (ii) a survey on Academic Reputation and (iii) the Scopus database. The selected indicators are 13 (central column of Figure 1), organized in 5 pillars (right-hand column). The weights of the indicators are adjusted depending on the goal of the ranking, but, globally, they are represented by the thickness of their respective lines in Figure 1. 
The criticism levelled at this ranking shares many elements with that directed at ARWU, in particular the excessive weight given two pillars, research and citations, although THE can be considered more balanced regarding information collection (e.g., the Scopus database includes far more references than WoS to publications in the field of human and social sciences and to publications in languages other than English). Still, besides this general criticism, THE is largely based on a reputational survey which provides two indicators of greater weight: research reputation and teaching reputation. The use of this kind of subjective indicators has come under severe criticism, since the territorial provenance of the experts consulted makes it impossible for them to know universities from all over the world and thus emit such a final judgment as is the rating of universities (see e.g. Sanz-Casado, 2015). Anyway, such scholars as R. Lacroix and L. Maheu claim that this new methodology of THE will "leave its mark" and in future this will become the ranking "of reference internationally" (Lacroix and Maheu, 2015: 46).

\section{Brazil: Folha University Ranking (RUF)}

In a setting of rankings focussing on the performances of global universities, the so-called world class universities, with institutional goals and structures aiming at attracting students globally, a ranking specifically geared to national universities emerged in Brazil: Folha University Ranking (RUF).

Published for the first time in 2012, RUF is the product of the initiative of an important media group of the State of Sao Paulo, with national influence, visibility and repercussion. It has been published yearly since that date and in 2015 it incorporated two main products: the ranking of the 192 Brazilian universities (public and private, including confessional and community) and the rankings of the 40 undergraduate programmes with the highest number of new students.

The university ranking is built from five general indicators: quality of research (42\%), quality of teaching (32\%), market evaluation (18\%), innovation (4\%) and internationalization (4\%). Table 1 organizes this information and presents the individual indicators which comprise each of the five general indicators. 
Teodoro,Santos \& Costa Junior: University rankings: between market regulation and the diffusion of organizational models

Table 1. Indicators used by Folha University Ranking (RUF) in 2017

\begin{tabular}{|c|c|c|}
\hline General Indicators & Individual indicators & Weight \\
\hline $\begin{array}{l}\text { Quality of research } \\
\text { Total: } 42 \text { points }\end{array}$ & $\begin{array}{l}\text { - Total publications: Number of papers published by the university in the } \\
\text { periodicals indexed by the WoS in } 2013 \text { and } 2014 \\
\text { - Total citations: Measures the relevance of scientific studies conducted } \\
\text { in the university based on the number of works which received citations in } \\
2015 \\
\text { - Citation per paper: Average number of citations made in } 2015 \text { to each } \\
\text { paper published and referenced in the WoS in } 2013 \text { and } 2014 \\
\text { - Publications per scholar: Average number of papers published by the } \\
\text { university's lecturers referenced in the WoS in } 2015 \\
\text { - Citations per scholar: Average number of citations received by the } \\
\text { university's faculty in } 2015 \\
\text { - Publications in national journals: Number of papers published in Brazilian } \\
\text { journals indexed by Scielo } \\
\text { - Resources captured: Average worth of financial resources obtained by the } \\
\text { faculty from state and federal science funding agencies } \\
\text { - CNPq grant holders: Percentage of the university's faculty considered } \\
\text { especially productive by the CNPq (scholars who received the so-called } \\
\text { productivity grant). } \\
\text { - Theses: Average number of theses submitted in } 2015 \text {, by lecturer }\end{array}$ & $\begin{array}{l}2 \\
2\end{array}$ \\
\hline $\begin{array}{l}\text { Quality of teaching } \\
\text { Total: } 32 \text { points }\end{array}$ & $\begin{array}{l}\text { - Evaluators of MEC: Survey conducted by Datafolha in 2015, } 2016 \text { and } \\
2017 \text { with a sample of 2,224 lecturers distributed throughout the country to } \\
\text { analyse the quality of tertiary education } \\
\text { - Lecturers with master's and PhD degrees: Percentage of lecturers who } \\
\text { hold a master's and a PhD degree ( } 2015 \text { census) } \\
\text { - Full- and part-time lecturers: Percentage of lecturers who work full time or } \\
\text { part time ( } 2015 \text { census) } \\
\text { - ENADE Grade: average university grade in the } 2013,2014 \text { and } 2015 \\
\text { National Student Performance Exam }\end{array}$ & 4 \\
\hline $\begin{array}{l}\text { Market assessment } \\
\text { Total: } 18 \text { points }\end{array}$ & $\begin{array}{l}\text { - Considers the opinion of 5,793 HR professionals consulted by Datafolha in } \\
2015,2016 \text { and } 2017 \text { regarding hiring preference }\end{array}$ & 18 \\
\hline $\begin{array}{l}\text { Internacionalization } \\
\text { Total: } 4 \text { points }\end{array}$ & $\begin{array}{l}\text { - International citations per lecturer: Average number of international } \\
\text { citations received by papers published by the university's lecturers (WoS) } \\
\text { - Publications in international co-authorship: Percentage of papers written in } \\
\text { collaboration with foreign researchers vis-à-vis the institution's total number } \\
\text { of papers (WoS) }\end{array}$ & 2 \\
\hline $\begin{array}{l}\text { Innovation } \\
\text { Total: } 4 \text { points }\end{array}$ & - Number of patents filed by the university in ten years (2006-2015) & 4 \\
\hline
\end{tabular}


Moreover, the (undergraduate) programme ranking stems from two general criteria: quality of teaching (64\%) and market evaluation (36\%), using the same individual indicators as the university ranking. The sum of these two general indicators provides the information used to order the programmes. The universe of these programmes extrapolates that of the university ranking, since undergraduate programmes can be offered by higher education institutions that are not part of the main evaluation of RUF (e.g. university centres and faculties, which do not have university status) ${ }^{3}$.

\section{Locating and interpreting rankings in the light of the Brazilian reality}

Upon reviewing the criteria which organize global rankings, it becomes evident that they take as institutional model the so-called world class universities, generally defined as research universities. In this sense, the adopted perspective is that they become attraction centres for students from other countries and a training locus of intellectual resources for consumption in global markets.

For the purpose of transnational regulation, a comparison between ARWU and THE makes it possible to claim that the latter is grounded on broader academic and scientific activities, achieving as end result final indicators that produce a more nuanced score, more comprehensive in scope. Let us take as examples the indicators relative to the application of new knowledge in companies in the item innovation, which is a way of measuring and characterizing the relations between the productive world and the university scientific output; or else the count of data relative to the teaching mission, underestimated in ARWU. The use of the European database Scopus to measure scientific output enables the locus of publication to be expanded, making it broader and more diversified than that of WoS in terms of publication languages and scientific fields (greater presence of social sciences and humanities), not limiting the identification of university research influence to the number of citations of papers in publications such as Nature or Science. Finally, it must be noted that the teaching dimension has been integrated, with remarkable weight, associated with the national diversity of students, which also suggests a measure of internationalization, seen as the ability to attract students from other parts of the world.

Although THE takes into account broader data than ARWU, which already makes it, in the comparison undertaken here, more relevant for the qualification of the various aspects of the university institutional mission, it still suffers from excessive endogenous referencing. In other words, it proposes a statistical - and, by extension, scientific - relevance to the circulation of ideas and knowledge within the actual academic community, giving little weight to outside impact indicators, be they related to industry or other production field, or social and cultural. 
And more: neither ranking even mentions possible orientations, and respective impact, of knowledge output or exchange in shaping social policies and technologies in the life of communities and populations. The question should be whether there is no satisfactory output (or, simply, whether there is no dissemination) of knowledge for the development of technologies applied to social problems, or whether extra-university problems do not matter or do not agree with the missions of a knowledge-producing agency. In the same way, one may question the discredit the teaching function seems to have been relegated to, since the classifying measures do not comprehend activities linked to teaching results in professional training, let alone in citizen integration - in other words, and to formulate the issue as a question: doesn't higher education contribute to social cohesion as well as economic and social development?

Folha University Ranking (RUF) shows some substantial differences from the international rankings ARWU and THE considered here. Examples of this are the presence of evaluation criteria which take into account the hiring demand of labour markets and the specificities as well as the performance of professional programmes, as a result of the introduction of the results of a comprehensive survey conducted by the Datafolha institute ${ }^{4}$ with nearly six thousand Human Resources professionals in corporations and social organizations operating in Brazil.

This focus on the domestic labour market sets the two main goals of RUF: on the one hand, to steer the demand for higher education by the elites (economic, social and educational) towards programmes with higher employability; on the other hand, to provide indications which may be considered useful for the labour market when it comes to recruiting better qualified professionals. In THE, the labour market dimension has residual weight (2.5\%), while in ARWU it is not even considered. This national (domestic) dimension of RUF is stronger, with a weight of $18 \%$, in the university ranking, rising to $36 \%$ in the programmes' ranking, given to the opinion of the evaluators from INEP-MEC invited to conduct the institutional assessment within the scope of the National System of Higher Education Evaluation (Sinaes) $)^{5}$. Table 2 shows the Top 20 Brazilian universities, according to Folha de São Paulo's 2017 ranking. 
Table 2: Top 20 Brazilian Universities, 2017

\begin{tabular}{|c|c|c|c|c|c|c|c|c|c|}
\hline \multirow[b]{2}{*}{ 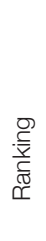 } & \multirow[b]{2}{*}{ Name of the University } & \multirow[b]{2}{*}{ 焉 } & \multirow[b]{2}{*}{ 을 } & \multicolumn{5}{|c|}{$\begin{array}{l}\text { Rank on Different } \\
\text { Categories }\end{array}$} & \multirow[b]{2}{*}{ 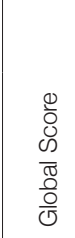 } \\
\hline & & & & 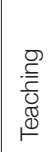 & $\begin{array}{l}\text { o } \\
\mathbb{0} \\
\mathbb{8} \\
\mathbb{8} \\
\mathbb{8} \\
\square\end{array}$ & 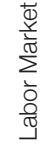 & 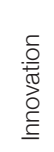 & 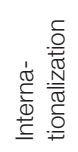 & \\
\hline 1 & Universidade Federal do Rio de Janeiro (UFRJ) & RJ & Public & 2 & 4 & 3 & 6 & 3 & 97.42 \\
\hline 2 & Universidade Estadual de Campinas (UNICAMP) & $\mathrm{SP}$ & Public & 3 & 2 & 11 & 2 & 10 & 97.31 \\
\hline 3 & Universidade de São Paulo (USP) & SP & Public & 9 & 1 & 1 & 1 & 2 & 97.24 \\
\hline 4 & Universidade Federal de Minas Gerais (UFMG) & MG & Public & 1 & 6 & 2 & 3 & 8 & 96.81 \\
\hline 5 & Universidade Federal do Rio Grande do Sul (UFRGS) & RS & Public & 4 & 5 & 14 & 5 & 14 & 95.86 \\
\hline 6 & Universidade Federal de Santa Catarina (UFSC) & SC & Public & 6 & 8 & 22 & 8 & 11 & 93.16 \\
\hline 7 & Universidade Estadual Paulista Júlio de Mesquita Filho (UNESP) & $\mathrm{SP}$ & Public & 13 & 7 & 7 & 7 & 21 & 93.15 \\
\hline 8 & Universidade Federal do Paraná (UFPR) & PR & Public & 8 & 10 & 11 & 4 & 23 & 92.82 \\
\hline 9 & Universidade de Brasilia (UNB) & DF & Public & 5 & 15 & 22 & 10 & 13 & 91.61 \\
\hline 10 & Universidade Federal de São Carlos (UFSCAR) & SP & Public & 7 & 9 & 37 & 16 & 15 & 90.92 \\
\hline 11 & Universidade Federal de Pernambuco (UFPE) & PE & Public & 11 & 17 & 9 & 11 & 26 & 90.65 \\
\hline 12 & Universidade Federal do Ceará (UFC) & CE & Public & 18 & 11 & 11 & 12 & 6 & 90.34 \\
\hline 13 & Universidade Federal de Viçosa (UFV) & MG & Public & 12 & 13 & 48 & 14 & 45 & 87.18 \\
\hline 14 & Universidade do Estado do Rio de Janeiro (UERJ) & RJ & Public & 31 & 12 & 9 & 43 & 9 & 86.84 \\
\hline 15 & Universidade Federal da Bahia (UFBA) & BA & Public & 21 & 21 & 16 & 9 & 19 & 86.72 \\
\hline 16 & Universidade Federal Fluminense (UFF) & RJ & Public & 15 & 24 & 19 & 31 & 24 & 86.37 \\
\hline 17 & Universidade Federal de Santa Maria (UFSM) & RS & Public & 14 & 18 & 48 & 20 & 37 & 85.41 \\
\hline 18 & Pontifícia Universidade Católica do Rio Grande do Sul (PUCRS) & RS & Private & 29 & 20 & 16 & 16 & 12 & 85.01 \\
\hline 19 & Universidade Federal de São Paulo (UNIFESP) & SP & Public & 10 & 3 & 99 & 39 & 18 & 84.97 \\
\hline 20 & Pontifícia Universidade Católica do Rio de Janeiro (PUC-RIO) & RJ & Private & 29 & 19 & 22 & 35 & 5 & 84.64 \\
\hline
\end{tabular}

Source: Ranking Folha de São Paulo. Available at http://ruf.folha.uol.com.br/2017/ranking-deuniversidades, accessed 28.02.2018

Even if the watchword of the contemporary reshaping of higher education is the implementation of the model of world class universities, and this model emphasizes the importance of internationalization, RUF shows rather a strong relation with the national dimension, giving internationalization a weight of only $4 \%$. Moreover, the item quality of research in RUF incorporates the publication in national periodicals and punctuates the condition of researchers-grant holders who have research projects submitted and regularly funded by the Brazilian agencies that support scientific research. 
It is somewhat surprising that the Brazilian ranking does not take into due consideration the evaluation of Master and PhD programmes (known in Brazil as stricto sensu), conducted by the CAPES Foundation. Indeed, it is within the scope of these graduate programmes that institutionalized research can be found with more vigour and structure, and also it is to them that an amount of academic prestige is given, due to the regular scientific output, with defined research lines and a structure invested with human and scientific means.

RUF takes the research university as its model. Just check the criteria used, which consider activities that, both in legislation and the tradition of the Brazilian university, are understood as integral: research, teaching and university extension. And, precisely for this reason, it presents a classification framework which concerns only academic organizations given the name of university, disregarding a fairly broader and more diversified set of higher education institutions (different missions and training goals, focus on teaching, technological education), which weigh heavily in the configuration of the country's higher education system. According to the 2016 census (INEP, 2017), of the $8,404,701$ Brazilian students enrolled in undergraduate programmes, only $53.7 \%$ attended universities (whether public or private). The remainder attended mostly faculties, in their vast majority private (1,866 from a total of 2,407 institutions), where research is not compulsory. And, among the universities, we find the large private universities, almost exclusively teaching universities, staffed with hourly-paid lecturers, with workloads that come to 40 hours of weekly teaching.

Still, for the classification purposes of this ranking, as well as of the international rankings ARWU and THE, the activities commonly known as university extension are not duly considered. These are precisely the activities where clearly the bridges between science-knowledge and society can be built, an important step towards fostering the generation of a public science (see, for sociology, Burowoy, 2005), certainly more closely bound to popular demand and the democratization of knowledge.

Besides, and this is probably a more significant aspect, there is the issue of social relevance and the university system's response to projects outside the hegemonic models of university. For research universities, innovation and internationalization are decisive factors in academic quality; but for universities that are committed to other dimensions, namely social inclusion (on pedagogical, curricular, social, linguistic-cultural levels), or local development and regional integration, there may be other categories that signal the social relevance of these institutions, and hence their academic quality. Yet the dimension of social relevance is absent both from the international rankings ARWU and THE and from RUF, except in the consideration of patent filing. 


\section{Conclusions}

The role played by international rankings as well as by their national versions in the reshaping of universities and higher education policies is unequivocal. The ARWU and THE rankings take world class universities as their ideal, with an extremely strong research component, giving them the reputation (and other indicators) that enable them to integrate the world TOP 500. Although RUF displays more hybrid characteristics, valuing the dimension "reputation in the labour market" or "employability" as well, what we have seen essentially is that RUF's ordering coincides, to a large extent, with the performance ranking of universities in the field of R\&D.

A report commissioned by the CAPES Foundation from Clarivate Analytics presents a detailed analysis of the research conducted in Brazil (Cross, Thomson, and Sinclair 2017). The data contained in that report are crystal clear: it is public universities (federal or state) that are at the top of scientific output and enable Brazil to hold the $13^{\text {th }}$ place in the list of countries with more referenced papers. Table 3 shows a comparison between RUF 2017 (global value) and the place that the Clarivate Analytics report gives the 20 leading universities in scientific research.

Table 3. Leading Brazilian Universities. Rankings RUF 2017 and Clarivate Analytics (2011-2016)

\begin{tabular}{|l|c|c|}
\hline \multicolumn{1}{|c|}{ Universities } & $\begin{array}{c}\text { RUF } \\
2017\end{array}$ & $\begin{array}{c}\text { Ranking Clarivate } \\
\text { Analytics }\end{array}$ \\
\hline Universidade Federal do Rio de Janeiro (UFRJ) & 1 & 4 \\
\hline Universidade Estadual de Campinas (UNICAMP) & 2 & 3 \\
\hline Universidade de São Paulo (USP) & 3 & 1 \\
\hline Universidade Federal de Minas Gerais (UFMG) & 4 & 6 \\
\hline Universidade Federal do Rio Grande do Sul (UFRGS) & 5 & 5 \\
\hline Universidade Federal de Santa Catarina (UFSC) & 6 & 9 \\
\hline Universidade Estadual Paulista Júlio de Mesquita Filho (UNESP) & 7 & 2 \\
\hline Universidade Federal do Paraná (UFPR) & 8 & 8 \\
\hline Universidade de Brasília (UNB) & 9 & 13 \\
\hline Universidade Federal de São Carlos (UFSCAR) & 10 & 14 \\
\hline Universidade Federal de Pernambuco (UFPE) & 11 & 11 \\
\hline Universidade Federal do Ceará (UFC) & 12 & 16 \\
\hline Universidade Federal de Viçosa (UFV) & 13 & 12 \\
\hline Universidade do Estado do Rio de Janeiro (UERJ) & 14 & 10 \\
\hline Universidade Federal da Bahia (UFBA) & 15 & 19 \\
\hline Universidade Federal Fluminense (UFF) & 16 & 17 \\
\hline Universidade Federal de Santa Maria (UFSM) & 17 & 15 \\
\hline Pontifícia Universidade Católica do Rio Grande do Sul (PUCRS) & 18 & n.a. \\
\hline Universidade Federal de São Paulo (UNIFESP) & 19 & 7 \\
\hline Pontifícia Universidade Católica do Rio de Janeiro (PUC-RIO) & 20 & n.a. \\
\hline
\end{tabular}


The analysis of these data comes across as contradicting the prevailing discourse in Brazil, which is very critical of the public sector of higher education. No profit-seeking private university is found in RUF's Top 50. Of the seven universities classified in that top 50 as private, six are confessional (five Catholic and one Presbyterian) and the remainder is a community university ${ }^{6}$. The universities considered to be excellent by RUF are public, all of which assuming a model which emphasises research, along with teaching (and, to some extent, university extension), in an effort to come closer to the model of world class universities established by international rankings.

Therefore, it is only by ideological impulse that one can understand that the World Bank would echo the critical voices on Brazilian public universities. In a report on equity and efficiency in public spending in Brazil (World Bank, 2017), without questioning the reasons why public universities show a cost two to five times higher than private universities, the World Bank puts forward a set of proposals which, should they be taken into consideration by the Brazilian authorities, would definitely put Brazil in the periphery of the global scientific and higher education system. But that is another matter that deserves empirical work to build evidence which will enable the country to deepen the democratization policies of higher education by improving the rationality of public spending.

\section{Note}

Translated by Isabel Canhoto from the Portuguese original. This paper was supported by the Portuguese Foundation for Science and Technology (FCT).

\section{Notes}

1 In the critical review we follow Lacroix e Maheu (2015: 32-35) closely.

2 Quacquarelli Symonds went on to present its own ranking, QS World University Ranking, based on these six indicators: (i) academic reputation; (ii) employer reputation; (iii) faculty/student ratio; (iv) citations per faculty; (v) international faculty ratio; and (vi) international student ratio. Information available at http://www.qs.com/qs-world-university-rankings.html, accessed on 27/09/2015

3 Under Brazilian law, the higher education system is organized in three types of institutions: universities, university centres and faculties. The element that fundamentally distinguishes each of these levels is the presence (or absence) of research. Faculties do not need to conduct research and university centres may have very limited ties to it. For in-depth information on the evolution of Brazilian higher education in the past 50 years see Vieira and Nogueira (2017).

4 The Datafolha institute is a research and IT department of the Grupo Folha media corporation, owner of, among others, the newspaper Folha de São Paulo, the internet provider UOL and Publifolha publishing house.

5 These evaluators are recruited ad hoc by the institute responsible at the Ministry of Education (MEC). They mostly work at public federal universities.

6 This is the University of Caxias do Sul (UCS), holding the 42nd place. The entity that holds it is a private-law, non-profit Foundation of the same name. In Brazil, this kind of universities is part of the community sector, or third sector. 


\section{References}

Burowoy, M. (2005). Presidential Address 2004. For Public Sociology. American Sociological Review, 70: 4-28.

Cross, D., Thomson, S. \& Sinclair, A. (2017, Dec.). Research in Brazil. A report for CAPES by Clarivate Analytics. Philadelphia: Clarivate Analytics. Available at http://www.capes.gov.br/images/stories/ download/diversos/17012018-CAPES-InCitesReport-Final.pdf. Acessed 27/02/2018.

Lacroix, R. \& Louis, M. (2015). Les grandes universités de recherche. Institutions autonomes dans un environement concurrentiel. Montréal: Les Presses de l'Universités de Montréal / Editions ESKA.

Lima, L. C. (2007). Educação ao Longo da Vida: Entre a Mão Direita e a Mão Esquerda de Miró. São Paulo: Cortez Editora.

Olssen, M. \& Peters, M.A. (2005). Neoliberalism, higher education and the knowledge economy: from the free market to knowledge capitalism. Journal of Education Policy, 20(3): 313-345. DOI: 10.1080/02680930500108718

Santiago, R. et al. (2008). Tertiary Education for the Knowledge Society. Vol. I: Special Features: Governance, Funding, Quality. Paris: OECD.

Tünnerman, C. \& Chauí, M. (2003). Challenges of the university in the knowledge society, five years after the World Conference on Higher Education. Paris: UNESCO.

UNESCO 2009. Global Education Digest 2009: Comparing Statistics Across the World. Montreal: UNESCO Institute for Statistics.

Vieira, S. L., \& Nogueira, J. (2017). Reformas da educação superior no Brasil: tempo(s) e movimento(s). Revista Lusófona de Educação, 35: 13-28. DOI: 10.24140/issn.1645-7250.rle35.01

World Bank. 2017. A fair adjustment : efficiency and equity of public spending in Brazil : Volume I : síntese (Portuguese). Washington, D.C. : World Bank Group. Available at http://documents.worldbank.org/ curated/en/884871511196609355/Nolume-I-s\%C3\%ADntese. Acessed 31/03/2018.

António Teodoro

Professor of Comparative and International Education, Universidade Lusófona de Humanidades e Tecnologias, Lisbon. Chair of the Standing Committee of WCCES and Portuguese Society of Comparative Education

(SPCE-SEC)

E-mail: teodoro.antonio@gmail.com ORCID: orcid.org/0000-0001-7819-0498 
Teodoro,Santos \& Costa Junior: University rankings: between market regulation and the diffusion of organizational models

Eduardo Santos

Sociologist. Professor and researcher at PPGE, Universidade Nove de Julho (Uninove), São Paulo. Academic director of the Popular University in Brazil

Project (Capes-Obeduc).

E-Mail: edusantos1959@gmail.com

Reinaldo da Costa Junior

PhD student at PPGE, Universidade Nove de Julho (PPGE / Uninove) and scholarship holder in the project "Popular University in Brazil"

(Obeduc / CAPES).

E-mail: dacostaj@gmail.com

ORCID: 0000-0001-9024-7290

Address

António Teodoro

Institute of Education

Universidade Lusófona de Humanidades e Tecnologias

Campo Grande, 376

1749-024 Lisbon, Portugal

Received: May 2018

Accepted: July 2018

Published: October 2018 